\title{
Democracy and Reforms: Evidence from a New Dataset Online Appendix
}

\author{
By Paola Giuliano, Prachi Mishra, and Antonio Spilimbergo
}

Table 1-Appendix: Summary Statistics

\begin{tabular}{lccccc}
\hline \hline & & & & & \\
Variable & Obs & Mean & Std. Dev. & Min. & Max \\
\hline & & & & & \\
Change in reform index & 20,123 & 0.01 & 0.08 & -1 & 1 \\
Lagged democracy & 20,123 & 0.59 & 0.37 & 0 & 1 \\
Lagged reform_index & 20,123 & 0.40 & 0.37 & 0 & 1 \\
Lagged crisis (inflation>40) & 5,252 & 0.10 & 0.30 & 0 & 1 \\
Lagged real devaluation & 5,252 & 0.01 & 0.17 & -1.00 & 1.30 \\
Lagged public expenditure as a percent of GDP & 5,252 & 15.06 & 5.18 & 2.98 & 34.39 \\
Lagged bureaucratic quality & 5,252 & 2.54 & 1.14 & 0 & 4 \\
Lagged tertiary enrollment & 5,252 & 0.27 & 0.22 & 0.00 & 0.97 \\
Lagged reforms in geographical neighbor & 5,252 & 0.02 & 0.03 & -0.21 & 0.22 \\
Lagged dummy for left & 5,252 & 0.33 & 0.47 & 0 & 1 \\
Lagged dummy for presidential & 5,252 & 0.55 & 0.50 & 0 & 1 \\
Lagged democracy in political neighbors & 18,970 & 1.25 & 5.12 & -9 & 10 \\
Lagged crisis (growth<0) & 5,234 & 0.26 & 0.44 & 0 & 1 \\
Terms of trade shocks & 5,252 & -0.01 & 0.14 & -0.70 & 0.47 \\
Lagged crisis (debt) & 4,679 & 0.01 & 0.12 & 0 & 1 \\
Lagged crisis (bank) & 4,679 & 0.05 & 0.22 & 0 & 1 \\
Lagged reform in trade neighbors & 5,252 & 0.01 & 0.03 & -0.21 & 0.39 \\
Change in reform index (principal component) & 1,418 & 0.02 & 0.04 & -0.18 & 0.31 \\
Lagged reform index (principal component) & 1,418 & 0.50 & 0.25 & 0 & 1.00 \\
Political reform (Giavazzi and Tabellini, 2005) & 22,565 & 0.20 & 0.40 & 0 & 1 \\
\hline \hline
\end{tabular}

Note: The summary statistics correspond to samples used in Tables 4, 5, 611,12 and 14. 
Table 2-Appendix: Panel Unit Root Test (Reform)

\begin{tabular}{|c|c|c|c|c|c|c|c|}
\hline & Agriculture & Prod. Mkt & Trade & Cap. Acc. & $\begin{array}{l}\text { Curr. } \\
\text { Acc. }\end{array}$ & Finance & $\begin{array}{c}\text { Polity2 } \\
\text { (overall sample) }\end{array}$ \\
\hline Levin-Lin ADF-stat & 2.93 & 1.63 & -2.57 & -2.46 & -1.39 & -1.50 & -1.53 \\
\hline Im, Pesharan \& Shin ADF-stat & 1.71 & -0.63 & -5.91 & -3.25 & -3.86 & -1.70 & -5.17 \\
\hline Number of countries & 91 & 118 & 95 & 71 & 60 & 71 & 135 \\
\hline Number of years & 43 & 44 & 44 & 31 & 44 & 31 & 44 \\
\hline
\end{tabular}

Note: The missing values for intermediate years have been interpolate to apply the unit root tests. All reported values are distributed $\mathrm{N}(0,1)$ under null of unit root or no cointegration. Large negative values imply rejection of the unit root, with the $5 \%$ and $10 \%$ critical values being -1.64 and 1.28 respectively. 
Table 3-Appendix: Reforms and Democracy, robustness to controls: Sample

\begin{tabular}{lcccccc}
\hline \hline \multicolumn{6}{l}{ Dependent variable: reform in (country, sector, year) } \\
\hline & $(1)$ & $(2)$ & $(3)$ & $(4)$ & $(5)$ & $(6)$ \\
\hline \multirow{2}{*}{ Lagged democracy } & $0.11^{* * *}$ & $0.014^{* *}$ & $0.044^{* * *}$ & $0.011^{* * *}$ & $0.014^{* * *}$ & $0.039^{* *}$ \\
& {$[0.004]$} & {$[0.006]$} & {$[0.014]$} & {$[0.003]$} & {$[0.004]$} & {$[0.016]$} \\
& & & & & & \\
Lagged level of index & $-0148^{* * *}$ & $-0.207^{* * *}$ & $-0.402^{* * *}$ & $-0.135^{* * *}$ & $-0.173^{* * *}$ & $-0.415^{* * *}$ \\
& {$[0.004]$} & {$[0.006]$} & {$[0.011]$} & {$[0.004]$} & {$[0.05]$} & {$[0.012]$} \\
\hline Observations & & & & & & \\
\hline \hline
\end{tabular}

Note: All regressions are restricted to corresponding samples in Table 4. The estimators are within estimators and allow for first-order autoregressive disturbance term. All regressions control for country sector, year fixed effects and country*sector and sector*year interactions. Standard errors are denoted in parentheses. ***, ** and ${ }^{*}$ denote statistical significance at 1,5 and 10 percent respectively. 
Table 4-Appendix: Reform Reversal and Democracy

\begin{tabular}{lcccc}
\hline \multicolumn{5}{c}{ Dependent variable: dummy for reform reversal in country, sector, year } \\
\hline & $(1)$ & $(2)$ & $(3)$ & $(4)$ \\
\hline \multirow{2}{*}{ Lagged democracy } & -0.006 & -0.009 & -0.008 & -0.009 \\
& {$[0.014]$} & {$[0.017]$} & {$[0.014]$} & {$[0.018]$} \\
Lagged level of index & $0.118^{* * *}$ & $0.210^{* * *}$ & $0.115^{* * *}$ & $0.212^{* * *}$ \\
& {$[0.013]$} & {$[0.018]$} & {$[0.014]$} & {$[0.020]$} \\
Country FE & $\mathrm{Y}$ & $\mathrm{Y}$ & $\mathrm{Y}$ & $\mathrm{Y}$ \\
Sector FE & $\mathrm{Y}$ & $\mathrm{Y}$ & $\mathrm{Y}$ & $\mathrm{Y}$ \\
Year FE & $\mathrm{Y}$ & $\mathrm{Y}$ & $\mathrm{Y}$ & $\mathrm{Y}$ \\
Country*Sector FE & & $\mathrm{Y}$ & & $\mathrm{Y}$ \\
Sector*Year FE & \multicolumn{5}{r}{} & $\mathrm{Y}$ & $\mathrm{Y}$ \\
& & & & \\
\hline Observations & 20,123 & 20,123 & 20,123 & 20,123 \\
\hline \hline
\end{tabular}

Note: The regressions are estimated by OLS. Reform reversal is defined by a decrease in the level of the reform index. Standard errors are denoted in parentheses. ${ }^{* *},{ }^{* *}$ and ${ }^{*}$ denote statistical significance at 1,5 and 10 percent respectively. 